\title{
No relationship between identified variants in the uncoupling protein 2 gene and energy expenditure
}

\author{
Mia Klannemark ${ }^{1}$, Marju Orho ${ }^{1}$ and Leif Groop ${ }^{1,2}$ \\ ${ }^{1}$ Department of Endocrinology, Malmö University Hospital, Lund University, Malmö, Sweden and ${ }^{2}$ Department of Medicine, \\ Helsinki University Hospital, Helsinki, Finland \\ (Correspondence should be addressed to L Groop, Wallenberg Laboratory, Endocrinology and Diabetes, Floor 3, UMAS Entrance 46. \\ 20502 Malmö, Sweden)
}

\begin{abstract}
Objective: The uncoupling protein 2 (UCP2) uncouples respiration from the oxidative phosphorylation in most cell types, predominantly in white fat and skeletal muscle. Since a decreased basal metabolic rate (BMR) would increase the susceptibility to weight gain, genetic alterations in the UCP2 gene could contribute to the pathogenesis of obesity and the metabolic syndrome (MSDR).

Design and methods: To test this hypothesis, we PCR amplified the introns of the UCP2 gene and sequenced the exon/intron boundaries. This information was used to construct intronic primers and to screen obese patients with low BMR for mutations in the coding regions of the UCP 2 gene, using the single-strand conformational polymorphism technique. Furthermore, we examined whether there is an association between a biallelic marker in the UCP2 gene and BMR or MSDR.

Results: The UCP2 gene is composed of six coding exons, covering $5 \mathrm{~kb}$ of chromosome 11q13. One polymorphism, but no mutations, were identified in the coding regions of the UCP2 gene. There were no significant differences in the allele or genotype frequencies of the Ala55Val polymorphism between 55 patients with MSDR and 46 healthy controls. No association was found between the UCP2 gene and BMR in patients with MSDR or in healthy controls.

Conclusions: Mutation screening and association studies suggest that mutations in the coding regions of the UCP2 gene do not affect BMR and do not contribute to increased susceptibility to obesity or MSDR. The results cannot, however, exclude the possibility that variants in regulatory elements of the gene could contribute to the development of obesity or MSDR.
\end{abstract}

European Journal of Endocrinology 139 217-223

\section{Introduction}

The uncoupling proteins (UCP) represent a family of proteins that uncouple the respiration from the oxidative phosphorylation in the inner mitochondrial membrane (1). For a long time, $\operatorname{UCP} 1(2,3)$ has been a marker for brown fat, a relatively abundant tissue in hibernating animals and newborns but less abundant in adults. The discovery of UCP2 and UCP3 isoforms in white fat and skeletal muscle (4-7) has relaunched the UCP genes as candidate genes for obesity, particularly as white fat and skeletal muscle can be expected to contribute more to variations in energy expenditure than the scarce brown fat $(8-12)$.

UCP2 is expressed in most tissues, with the highest mRNA concentrations found in white fat, skeletal muscle and cells of the immune system (4). It is known to be upregulated by leptin $(13,14)$, high-fat feeding (4) and the peroxisome proliferator-activated receptor-gamma agonist troglitazone (15). Recent results suggest that intracellular metabolism of free fatty acids may regulate the expression of UCP2 in adipose tissue (16). The UCP2 gene is located on chromosome $11 \mathrm{q} 13$
(4), a locus that has recently been linked to resting metabolic rate in the Quebec Family Study (17).

Abdominal obesity and dyslipidaemia with high verylow-density lipoprotein-triglyceride and low high-density lipoprotein (HDL)-cholesterol levels are strongly associated with non-insulin dependent diabetes mellitus (NIDDM) (18-25). This particular clinical picture is often referred to as the metabolic syndrome (MSDR; insulin resistance syndrome/syndrome X), which predisposes to the development of atherosclerosis and macrovascular disease (26) and is considered to have a strong genetic background. MSDR clusters in families and represents a genetic adaptation towards an energysaving phenotype with survival advantage during periods of famine (27). Therefore, genetic alterations in genes influencing energy expenditure seem likely to be involved in the polygenic background of MSDR.

To study whether alterations in the UCP2 gene contribute to the development of obesity or MSDR, we determined the exon/intron boundary sequences of the UCP2 gene and screened the coding regions and the exon/intron junctions for mutations in obese subjects with low basal metabolic rate (BMR). Using an amino 
Table 1 Clinical characteristics of subjects participating in the association study. Data are means \pm S.D.

\begin{tabular}{lcc}
\hline & MSDR & Controls \\
\hline Number & 55 & 46 \\
Sex (F/M) & $28 / 27$ & $21 / 25$ \\
Age (years) & $61 \pm 13$ & $64 \pm 11$ \\
BMl (kg/m²) & $31.6 \pm 4.6^{\ddagger}$ & $23.3 \pm 2.7$ \\
WHR; men & $0.99 \pm 0.06^{\S}$ & $0.91 \pm 0.05$ \\
WHR; women & $0.91 \pm 0.08^{\dagger}$ & $0.79 \pm 0.06$ \\
Fatmass (\%); men & $29.6 \pm 8.9^{\S}$ & $18.9 \pm 5.2$ \\
Fatmass (\%); women & $37.1 \pm 5.7^{\S}$ & $29.1 \pm 4.0$ \\
Triglycerides (mmol/l) & $2.6 \pm 1.8^{\dagger}$ & $1.2 \pm 0.5$ \\
Cholesterol (mmol/l) & $5.9 \pm 1.2$ & $5.8 \pm 1.0$ \\
HDL cholesterol (mmol/l); men & $0.89 \pm 0.2^{*}$ & $1.2 \pm 0.3$ \\
HDL cholesterol (mmol/l); women & $1.0 \pm 0.3^{\S}$ & $1.6 \pm 0.5$ \\
Systolic blood pressure (mmHg) & $148 \pm 20^{*}$ & $137 \pm 22$ \\
Diastolic blood pressure (mmHg) & $82 \pm 8.6^{*}$ & $78 \pm 9.7$ \\
Fasting blood glucose (mmol/l) & $7.5 \pm 2.5^{\dagger}$ & $4.9 \pm 0.5$ \\
HbAlc (\%) & $6.6 \pm 1.7^{\dagger}$ & $4.9 \pm 0.4$ \\
Fasting serum insulin (nmol/l) & $13.0 \pm 8.1^{\dagger}$ & $8.1 \pm 11$ \\
BMR/LBM (kcal/kg LBM) & $27.4 \pm 3.0$ & -
\end{tabular}

${ }^{*} P<0.05,{ }^{\S} P<0.0005,{ }^{\dagger} P<1 \times 10^{-5}$ and ${ }^{\ddagger} P<1 \times 10^{-14}$ vs control subjects.

acid polymorphism identified in the second coding exon of the UCP2 gene, we examined whether this variant is associated with MSDR or decreased BMR.

\section{Materials and methods}

\section{Subjects and study design}

MSDR was defined in accordance with the recent proposition adopted by the World Health Organization (unpublished, 1997) suggesting that patients fulfilling at least three of the following criteria have MSDR: abdominal obesity, glucose intolerance, elevated blood pressure, elevated plasma triglyceride concentrations, decreased plasma HDL-cholesterol concentrations, microalbuminuria and insulin resistance. In this study, each patient defined as MSDR fulfilled at least three of the following criteria: waist-to-hip ratio (WHR) $>0.95$ for men and $>0.85$ for women, systolic/diastolic blood pressure $>160 / 90 \mathrm{mmHg}$, plasma triglycerides $>1.7 \mathrm{mmol} / \mathrm{l}$, plasma HDL-cholesterol $<1.0 \mathrm{mmol} / \mathrm{l}$ for men and $<1.1 \mathrm{mmol} / \mathrm{l}$ for women, albumin excretion rate $>20 \mu \mathrm{g} / \mathrm{min}$ and impaired glucose tolerance or NIDDM (28).

Mutation screening Thirty (16 males, 14 females) unrelated Swedish obese patients with low BMR were selected (age 58.2 \pm 13 years, body mass index (BMI) $31.1 \pm 3.6 \mathrm{~kg} / \mathrm{m}^{2}$, BMR $25.9 \pm 1.8 \mathrm{kcal} / \mathrm{kg}$ lean body mass (LBM)). BMR was in the lowest quartile of a control population and BMI was $>27 \mathrm{~kg} / \mathrm{m}^{2}$ for these patients. Twenty-five of them fulfilled the criteria for MSDR as given above.

Association study Fifty-five unrelated patients with MSDR (including the 25 from the mutation screening) and 46 unrelated healthy controls without signs of MSDR were selected from southern Sweden. Clinical characteristics of both study groups are shown in Table 1. Measurements of BMR were available from patients (range $21.1-39.6 \mathrm{kcal} / \mathrm{kg} \mathrm{LBM}$ ) but not from controls.

Assessment of the effect of the Ala $55 \mathrm{Val}$ genotype on BMR Fifty-one (26 males, 25 females) unrelated healthy controls with normal glucose tolerance and without known family history of diabetes, were selected from the Botnia region in western Finland. The clinical characteristics of these healthy subjects were: age $45 \pm 15$ years, BMI $24.0 \pm 2.6 \mathrm{~kg} / \mathrm{m}^{2}$, WHR $0.88 \pm$ 0.06 , fatmass $18.8 \pm 6.5 \%$ and BMR $30.7 \pm 4.9 \mathrm{kcal} /$ $\mathrm{kg}$ LBM (range $24.4-47.5 \mathrm{kcal} / \mathrm{kg} \mathrm{LBM}$ ). Of note, the MSDR patients included in the association study (see above) have significantly lower BMR than these controls (27.4 kcal/kg LBM vs $30.7 \mathrm{kcal} / \mathrm{kg} \mathrm{LBM}, P<0.0001)$.

\section{Determination of exon/intron boundaries with PCR and direct sequencing}

Using information about the exon/intron boundaries of the human UCP1 gene $(2,3)$, introns were positioned in the human UCP2 gene while assuming conserved exon/ intron structure between these genes. Exonic primers were constructed on both sides of each intron, and the introns were amplified by PCR (Table 2). The PCR reactions were performed with initial denaturation $\left(96^{\circ} \mathrm{C}\right.$ for $1 \mathrm{~min}$ ) followed by 30 cycles of denaturation $\left(94{ }^{\circ} \mathrm{C}\right.$ for $\left.20 \mathrm{~s}\right)$, annealing $\left(62^{\circ} \mathrm{C}\right.$ or $64^{\circ} \mathrm{C}$ for $30 \mathrm{~s}$; Table

Table 2 Sequences of exonic primers and PCR conditions for amplification of the introns of the UCP2 gene. All the primer sequences are given in $5^{\prime}$ to $3^{\prime}$ direction. The number in parenthesis after each primer sequence indicates the exon from which it was derived.

\begin{tabular}{|c|c|c|c|}
\hline Forward primer sequence & Reverse primer sequence & $\begin{array}{l}\text { Intron amplified } \\
\text { (product size, bp) }\end{array}$ & $\begin{array}{l}\text { Annealing temperature } \\
\left({ }^{\circ} \mathrm{C}\right)\end{array}$ \\
\hline $\begin{array}{l}\text { GTTCAAGGCCACAGATGTGCC (1) } \\
\text { TGGTTGCCGGCCTGCAGCG (2) } \\
\text { CATGCCAGCATTGGGAGCCG (3) } \\
\text { TGTTGCTCGTAATGCCATTGTC (4) } \\
\text { AGACGAGATACATGAACTCTGC (5) }\end{array}$ & $\begin{array}{l}\text { ACCATGGTCAGAATGGTGCCC (2) } \\
\text { TCCTCTCGGGCAATGGTCTTG (3) } \\
\text { AGGAGGGCATCCTTGATGAGG (4) } \\
\text { TCATGTATCTCGTCTTGACCAC (5) } \\
\text { TCAGAAGGGAGCCTCTCGGG (6) }\end{array}$ & $\begin{array}{l}1(357) \\
2(\sim 1100) \\
3(359) \\
4(\sim 1200) \\
5(584)\end{array}$ & $\begin{array}{l}64 \\
64 \\
64 \\
62 \\
62\end{array}$ \\
\hline
\end{tabular}


2) and extension $\left(72{ }^{\circ} \mathrm{C}\right.$ for $\left.1 \mathrm{~min}\right)$, followed by final extension $\left(72^{\circ} \mathrm{C}\right.$ for $\left.15 \mathrm{~min}\right)$. The reactions were performed in a total volume of $20 \mu \mathrm{l}$ with Tris buffer for Taq polymerase $(10 \mathrm{mmol} / \mathrm{l}$ Tris- $\mathrm{HCl}, \mathrm{pH} 8.3$; $50 \mathrm{mmol} / \mathrm{l} \mathrm{KCl} ; 0.01 \% \mathrm{w} / \mathrm{v}$ gelatin) and $1.5 \%$ formamide; $0.13 \mathrm{mmol} / \mathrm{l} \mathrm{dNTP;} 1.5 \mathrm{mmol} / \mathrm{l} \mathrm{MgCl}_{2} ; 0.2 \mu \mathrm{mol} / \mathrm{l}$ of both primers and $0.5 \mathrm{U}$ Taq polymerase (Perkin Elmer, Foster City, CA, USA) using 25 ng genomic DNA as a template. PCR products were sequenced using the ABI PRISM dye terminator cycle sequencing ready reaction kit (Perkin Elmer) and analysed on an automated sequencer (ABI, model 373, Perkin Elmer). Introns 1, 3 and 5 were sequenced bidirectionally in their entirety, whereas only the exon/intron border sequences were sequenced for introns 2 and 4. Exon/ intron borders were positioned by applying the GT/AG rule (29).

\section{Determination of the region upstream of the first coding exon by inverse PCR and direct sequencing}

Five micrograms genomic DNA isolated from a 50-yearold healthy Caucasian male were cut with $25 \mathrm{U}$ NcoI (New England Biolabs, Herts, UK) for $4 \mathrm{~h}$ in a total volume of $30 \mu \mathrm{l}$ using conditions recommended by the manufacturer. $\mathrm{NcoI}$ was then inactivated at $65^{\circ} \mathrm{C}$ for $20 \mathrm{~min}$, and $6 \mu \mathrm{l}$ of the digest were ligated in a total volume of $230 \mu \mathrm{l}$ with $50 \mathrm{U}$ T4 DNA ligase $(5 \mathrm{U} / \mu \mathrm{l}$, Appligene, Gaithersburg, MD, USA) at $16^{\circ} \mathrm{C}$ for $24 \mathrm{~h}$. In this procedure, the genomic DNA was cut at nucleotide 77 in the second coding exon and at an unknown position upstream of the coding region. Thus, a $2.3 \mathrm{~kb}$ long circular fragment containing approximately $2 \mathrm{~kb}$ upstream of the first coding exon was generated. Two rounds of PCR were then performed using nested primers; PCR 1 (annealing temperature $62^{\circ} \mathrm{C}, 35$ cycles) using the forward primer for fragment $2 \mathrm{~A}$ (Table 3) and 5'-TGATGAGATCTGCGATGCAGG-3' as the reverse primer and $2.0 \mu$ l ligation mixture as a template; PCR2 (annealing temperature $56^{\circ} \mathrm{C}, 25$ cycles) using $5^{\prime}$-TGGGAGTCTTGATGGTGTC-3' as the forward and $5^{\prime}$-AACTTCACAGTGGCAGTAGG- $3^{\prime}$ as the reverse primer and $0.5 \mu \mathrm{l}$ amplification product from PCR 1 as a template. PCR reactions were performed as for the exon/intron boundary PCR, but using $\mathrm{NH}_{4}^{+}$ buffer $\left(16 \mathrm{mmol} / \mathrm{l}\left(\mathrm{NH}_{4}\right)_{2} \mathrm{SO}_{4} ; 67 \mathrm{mmol} / \mathrm{l}\right.$ Tris, $\mathrm{pH} 8 \cdot 8$; $0.01 \%$ Tween 20) instead of the Tris-HCl and 5\% glycerol instead of $1.5 \%$ formamide. When sequencing the PCR product from PCR2, the sequence of $295 \mathrm{bp}$ of the region upstream of the first coding exon was acquired.

\section{Single-strand conformational polymorphism (SSCP)}

For the SSCP analysis (30), the six coding exons of the UCP2 gene were amplified with intronic primers (Table 3). For exons 1 and 2, overlapping sets of two (exon 1) or three (exon 2) primer pairs were used. A minimum distance of $25 \mathrm{bp}$ between the intronic primer and exon border was used for all fragments. PCR was performed as for the exon/intron boundary PCR, with the following changes: $0.5 \mu \mathrm{Ci}\left[\alpha_{-}{ }^{32} \mathrm{P}\right] \mathrm{dCTP}$ was added to each reaction; initial denaturation was set at $3 \mathrm{~min}$, cycle denaturation at $30 \mathrm{~s}$, cycle extension at $30 \mathrm{~s}$ and final extension at $10 \mathrm{~min}$. See Table 3 for variable annealing temperatures and buffers. The reactions were stopped with 95\% formamide buffer (1:1), denatured, cooled and electrophoresed on glycerol-free $(35 \mathrm{~W}$ for $3.5 \mathrm{~h}$ at $\left.4^{\circ} \mathrm{C}\right)$ and $5 \%$ glycerol $(8 \mathrm{~W}$ for $12 \mathrm{~h}$ at room temperature), non-denaturing $5 \%$ polyacrylamide gels (acrylamide/bisacrylamide 49:1). When differences in band pattern were observed, PCR products were sequenced bidirectionally.

\section{Genotyping the Ala55 Val polymorphism in the UCP2 gene}

One polymorphism was identified in codon 55 of the

Table 3 Primer sequences and variable conditions for PCR-SSCP analysis of the UCP2 gene. All the primer sequences are given in $5^{\prime}$ to $3^{\prime}$ direction. The primers for fragments $1 \mathrm{~A}$ and $1 \mathrm{~B}$ amplify two overlapping fragments of exon 1 . The primers for fragments $2 \mathrm{~A}-2 \mathrm{C}$ amplify three overlapping fragments of exon 2. The reverse primer for amplification of exon 6 is located at the end of the coding sequence.

\begin{tabular}{|c|c|c|c|c|}
\hline Forward primer sequence & Reverse primer sequence & $\begin{array}{l}\text { Exon amplified } \\
\text { (product size, bp) }\end{array}$ & $\begin{array}{c}\text { Annealing } \\
\text { temperature } \\
\left({ }^{\circ} \mathrm{C}\right)\end{array}$ & Buffer* \\
\hline TGAGGGACTTGGTTCTATTAGG & AACTTCACAGTGGCAGTAGG & $1 \mathrm{~A}(248)$ & 58 & TB \\
\hline GTTCAAGGCCACAGATGTGCC & AGCTACAGGGATAAGCATGTTGC & 1B (254) & 64 & TB \\
\hline TACTGCTAAAGTCCGGTTACAG & TGGTTGCCGGCCTGCAGCG & $2 A(247)$ & 62 & NB \\
\hline TGTCTTGGCCTTGCAGATCC & TTGGTGTAGAACTGTTTGCAG & 2B (215) & 58 & NB \\
\hline TCCTCTCGGGCAATGGTCTTG & AGGTGCTTAGGAACTATGTGG & $2 \mathrm{C}(256)$ & 60 & NB \\
\hline AGGTAGAAAATGAGTGCAAGC & GGGTGAGACCAGAGTATCG & $3(308)$ & 58 & TB \\
\hline CCTCTGGAAAGGTGTGTACCA & CGCACCTGCTCCTGGCATG & $4(255)$ & 62 & NB \\
\hline GAATGATGGGTGAAGATCTTGA & CATGCATAGCCAAGAGGCCTG & $5(277)$ & 60 & TB \\
\hline GGAAGTGGGAGGTGGAGGTG & TCAGAAGGGAGCCTCTCGGG & $6(165)$ & 64 & TB \\
\hline
\end{tabular}

* TB, tris-HCl buffer for Taq polymerase; NB, ammonium sulphate buffer. 


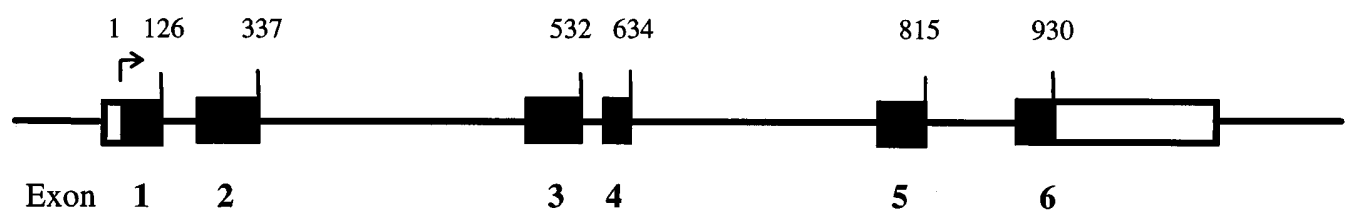

Figure 1 The exon/intron structure of the coding region of the human UCP2 gene. Exons are numbered starting from the first coding exon and shown with boxes. Filled boxes represent translated sequences and open boxes untranslated sequences. Introns are illustrated with black lines. Vertical lines indicate the last nucleotide in each exon, with the nucleotide sequence numbered from the first nucleotide in the translation initiation codon. The translation initiation codon is indicated with an arrow. The first coding exon starts $99 \mathrm{bp}$ upstream of the translation initiation codon, and exon 6 contains a $644 \mathrm{bp}$ non-translated region (5).

UCP2 gene changing a GCC (alanine) to a GTC (valine). This polymorphism was genotyped by PCR amplification of the genomic DNA using the forward primer for fragment $2 \mathrm{~A}$ together with a mismatch primer as the reverse primer (5'-CATCACACCGCGGTACTGGGCGTTG-3', mismatch underlined) that created a HincII site in sequences coding for a valine, followed by digestion with the HincII enzyme using conditions recommended by the manufacturer (Appligene), and finally electrophoretic separation on an agarose gel. PCR was performed as for the exon/intron boundary PCR, with the annealing temperature set at $62{ }^{\circ} \mathrm{C}$ and the initial denaturation set at $3 \mathrm{~min}$, cycle denaturation at $30 \mathrm{~s}$, cycle extension at $30 \mathrm{~s}$ and final extension at $10 \mathrm{~min}$.

\section{Statistical analyses}

Differences in allele and genotype frequencies between MSDR patients and control subjects were tested by $\chi^{2}$ analysis, and differences in clinical characteristics by the Mann-Whitney non-parametric test using the BMDP New System for Windows (Biomedical Data Processing, Los Angeles, CA, USA). A $P$ value of $<0.05$ was considered statistically significant.

\section{GenBank accession numbers}

The nucleotide sequences of the UCP2 gene were submitted to the EMBL Nucleotide Sequence Database with accession numbers AJ223477-AJ223479.

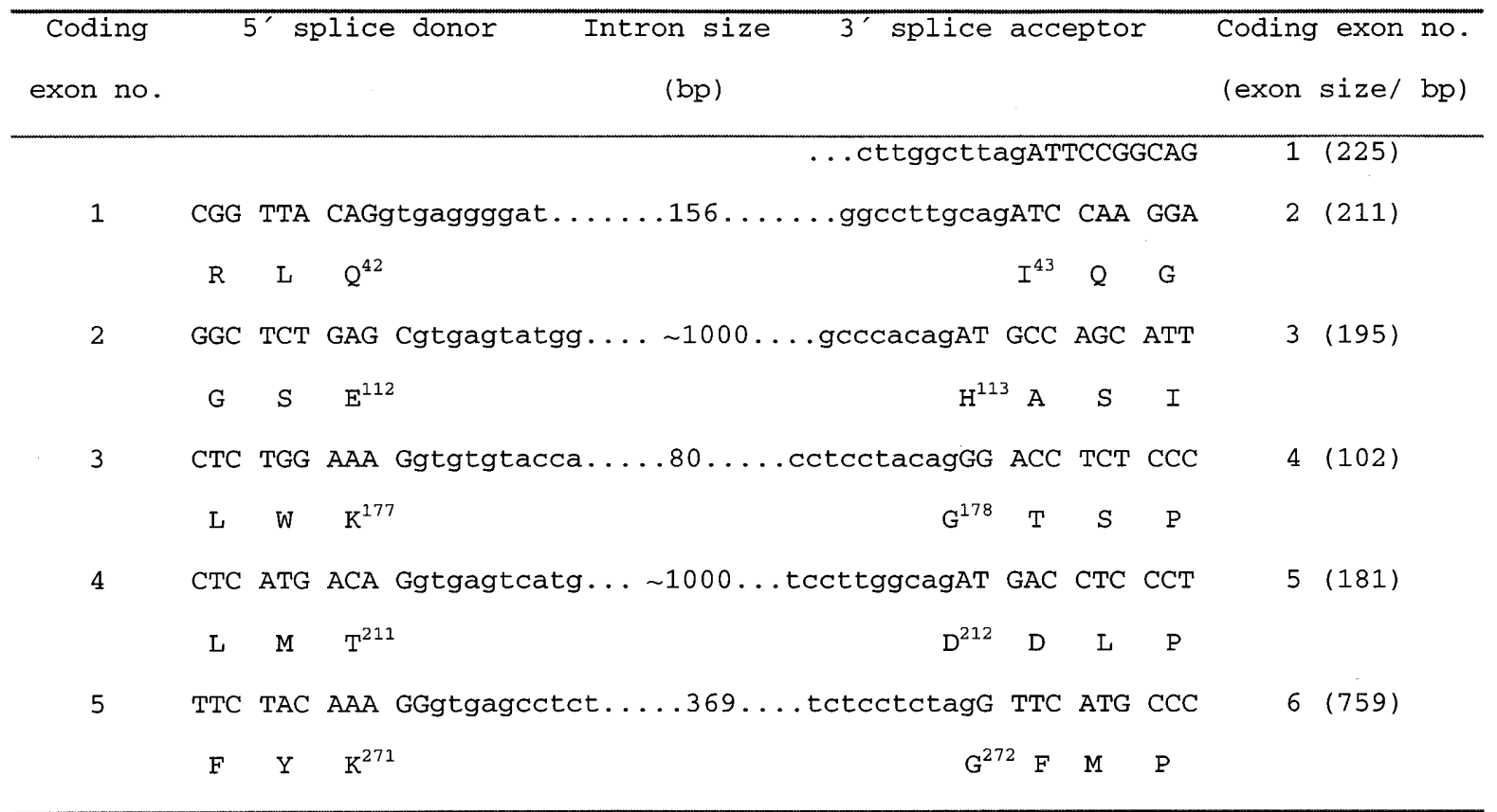

Figure 2 Sequences at the exon/intron junctions of the coding region of the human UCP2 gene. Exon sequences are given in uppercase letters, with encoded amino acids shown below the nucleotide sequence. Intron sequences are given in lowercase letters. Amino acids that precede, follow or are interrupted by introns are indicated with their codon number. Intron sizes were determined by sequencing (introns 1,3 and 5) or by size estimation of the PCR product on an agarose gel (introns 2 and 4). When comparing the coding region of the UCP2 gene with that of the human UCP1 gene (3), the exon/intron structure was conserved except that exon 2 of the UCP 1 gene is four amino acids shorter and exon 3 is two amino acids longer than corresponding exons of the UCP2 gene. Thereby, exon 2 of the human UCP1 gene is interrupted by intron 2 at $\mathrm{Thr}^{109}$ instead of at His ${ }^{113}$. The exon/intron structure of the coding region of the UCP2 gene is conserved also with the human UCP3gene (31), except that exon 3 of the UCP3 gene contains three additional amino acids and thus is interrupted by intron 3 at Gly ${ }^{181}$ instead of at Gly ${ }^{178}$. 
Table 4 Basal metabolic rate (kcal/kg LBM) in MSDR patients and healthy controls according to the Ala55Val genotype of the UCP2 gene.

\begin{tabular}{lcc}
\hline Genotype & $\begin{array}{c}\text { MSDR } \\
\text { (Sweden } n=55)\end{array}$ & $\begin{array}{c}\text { Controls } \\
\text { (Finland } n=51)\end{array}$ \\
\hline Ala/Ala & $27.6 \pm 3.0$ & $29.0 \pm 3.1$ \\
Ala/Val & $28.2 \pm 2.6$ & $30.7 \pm 5.2$ \\
Val/Val & $26.8 \pm 2.2$ & $30.6 \pm 2.7$ \\
\hline
\end{tabular}

\section{Results}

The UCP2 gene was found to be composed of six coding exons covering $5 \mathrm{~kb}$ of chromosome 11q13 (Fig. 1). All the exon/intron boundaries and exon sizes (coding exons) were similar to the structures of the human UCP1 (3) and UCP3 (31) genes (Fig. 2).

Mutation screening of the UCP2 gene in 30 obese patients with low BMR revealed one polymorphism (Ala55Val) in codon 55 of the UCP2 gene, changing an alanine (GCC) to a valine (GTC).

In healthy Finnish controls, the frequency of the alanine allele was $60.8 \%$ and that of the valine allele $39.2 \%$. There were no significant differences in BMR between healthy control subjects or MSDR subjects with different Ala55Val genotypes (Table 4). The allele frequencies and genotype distributions of the Ala55Val polymorphism did not differ significantly between 55 subjects with MSDR and 46 healthy controls (Table 5). Genotype frequencies were in Hardy-Weinberg equilibrium in all groups studied.

\section{Discussion}

The exon/intron structure of the coding region of the human UCP2 gene was similar to the structures of the human UCP 1 and UCP 3 genes. Information on the exon/intron boundaries of the six coding exons of the UCP2 gene allowed us to screen coding exons and

Table 5 Allele and genotype frequencies of the Ala55Val polymorphism in Swedish MSDR patients and healthy controls.

\begin{tabular}{lcc}
\hline Allele or genotype & $\begin{array}{c}\text { MSDR } \\
\%(n)\end{array}$ & $\begin{array}{c}\text { Controls } \\
\%(n)\end{array}$ \\
\hline Allele & & \\
Ala & & \\
Val & $50.0(55)$ & $53.3(48)$ \\
$\quad$ Total & $50.0(55)$ & $46.7(42)$ \\
Genotype & $100(110)$ & $100(90)$ \\
$\quad$ Ala/Ala & & \\
Ala/Val & $29.0(16)$ & $26.1(12)$ \\
Val/Val & $41.8(23)$ & $52.2(25)$ \\
Total & $29.0(16)$ & $19.6(9)$ \\
& $100(55)$ & $100(46)$
\end{tabular}

Neither allele nor genotype frequencies differ between MSDR patients and controls. flanking intronic regions for mutations in obese patients with low BMR.

Basal energy expenditure accounts for $60-70 \%$ of total energy expenditure (9), the rest being generated during exercise and food-induced thermogenesis. The variability of BMR is largely dependent on processes in non-adipose tissues (60-80\%) (9). Nevertheless, white adipose tissue could contribute to the small decrease needed to gain weight over time, and low BMR is a risk factor for weight gain (32).

Mice deficient in brown adipose tissue become obese and hyperinsulinemic (33). Surprisingly, targeted disruption of the UCP1 gene in mice does not result in obesity, a finding which led to the postulation of other UCP genes involved in this mechanism (34). No mutations that increase the susceptibility to obesity have been found in the coding region of the UCP 1 gene in obese humans (35). However, one polymorphism near the UCP1 gene, at nucleotide position -3826 , has been associated with increased weight gain during adult life (36), and the effect of this variant was enhanced when it occurred together with the Trp64Arg mutation in the $\beta 3$-adrenergic receptor gene (37).

In the present study, mutation screening of 30 obese patients with low BMR revealed one common variant in exon 2, Ala 55Val, but there was no difference in allele frequency between patients with MSDR and healthy controls. This is in accordance with a recent Danish study, in which no association was found between the same polymorphism and juvenile obesity (38). However, this study did not include measures of energy expenditure, a quantitative trait which may be more relevant to the genotype.

In accordance with these findings, highly polymorphic markers flanking the UCP 2 and UCP 3 genes $(4,33)$ were not linked to BMI or WHR in a study of sibling pairs (39). In contrast to this, the highly polymorphic marker D11S611 was reported to be tightly linked to resting metabolic rate in the Quebec Family Study (17). Consequently, it seems that this chromosomal region links to resting metabolic rate but not to obesity. However, in the present study the Ala55Val polymorphism was associated neither with decreased BMR (in patients with MSDR or in healthy controls) nor with obesity in patients with MSDR. There are several potential explanations for the discrepancy of these findings. First, the Ala55Val variant might not be in linkage disequilibrium with the variants responsible for the linkage found in the Quebec Family Study. Thus, the UCP 2 gene may still be important for the variability of metabolic rate, although in such cases this does not seem to influence susceptibility to obesity. Secondly, regions important for gene regulation were not included in our screening. Thus alleles responsible for the linkage found in the Quebec Family Study could be present in the promoter region or other regulatory parts of the $U C P 2$ gene or in the very closely located UCP 3 gene. On the other hand, if the linkage in the Quebec Family 
Study was explained by a variant in the promoter of the UCP2 gene, one would expect to find decreased expression of UCP 2 in obese individuals or in individuals with reduced BMR. However, in a recent study of UCP2 mRNA levels in adipose tissue and skeletal muscle, no difference was observed between lean and obese subjects and the level of expression did not correlate with BMR (16).

In conclusion, mutation screening and association studies suggest that mutations in the coding regions of the UCP2 gene do not affect BMR and do not contribute to increased susceptibility to obesity or MSDR. The results cannot, however, exclude the possibility that variants in regulatory elements of the gene could contribute to the development of obesity or MSDR.

\section{Acknowledgements}

This work was supported by grants from the Sigrid Juselius Foundation, the Albert Påhlssons Foundation, Malmö University Hospital, the Swedish Medical Research Council, the Novo Nordisk Foundation, the Swedish Diabetes Foundation and EEC grant BMH4CT95-0662.

\section{References}

1 Nicholls DG \& Locke RM. Thermogenic mechanisms in brown fat. Physiological Reviews $1984641-64$.

2 Bouillaud F, Ricquier D. Thibault J \& Weissenbach J. Molecular approach to thermogenesis in brown adipose tissue: cDNA cloning of the mitochondrial uncoupling protein. Proceedings of the National Academy of Sciences of the USA $198582445-448$.

3 Cassard AM, Bouillaud F, Mattei M-G, Hentz E, Raimbault S, Thomas $\mathrm{M}$ et al. Human uncoupling protein gene: structure, comparison with rat gene, and assignment to the long arm of chromosome 4. Journal of Cellular Biochemistry 199043 255-264.

4 Fleury C, Neverova M, Collins S, Raimbault S, Champigny O, Levi Meyrueis C et al. Uncoupling protein-2: a novel gene linked to obesity and hyperinsulinemia. Nature Genetics 199715 269-272.

5 Gimeno RE, Dembski M, Weng X, Deng N, Shyjan AW, Gimeno CJ et al. Cloning and characterization of an uncoupling protein homolog: a potential molecular mediator of human thermogenesis. Diabetes 199746 900-906.

6 Boss O, Samec S, Paoloni Giacobino A, Rossier C, Dulloo A, Seydoux $\mathrm{J}$ et al. Uncoupling protein-3: a new member of the mitochondrial carrier family with tissue-specific expression. FEBS Letters 1997408 39-42.

7 Vidal-Puig A, Solanes G, Grujic D, Flier JS \& Lowell BB. UCP3: an uncoupling protein homologue expressed preferentially and abundantly in skeletal muscle and brown adipose tissue. Biochemical and Biophysical Research Communications 1997235 79-82.

8 Leibel RL, Rosenbaum M \& Hirsch J. Changes in energy expenditure resulting from altered body weight. New England Journal of Medicine $1995332621-628$.

9 Ravussin E \& Bogardus C. A brief overview of human energy metabolism and its relationship to essential obesity. American Journal of Clinical Nutrition 199255 242-245.

10 Rosenbaum M, Leibel RL \& Hirsch J. Obesity. New England Journal of Medicine 1997337 396-407.

11 Simonsen L, Bulow J, Madsen J \& Christensen NJ. Thermogenic response to epinephrine in the forearm and abdominal subcutaneous adipose tissue. American Journal of Physiology 1992 263 E850-E855
12 Simonsen L, Stallknecht B \& Bulow J. Contribution of skeletal muscle and adipose tissue to adrenaline-induced thermogenesis in man. International Journal of Obesity and Related Metabolic Disorders 199317 S47-S51.

13 Scarpace PJ, Matheny M, Pollock BH \& Tumer N. Leptin increases uncoupling protein expression and energy expenditure. American Journal of Physiology 1997273 E226-E230.

14 Zhou YT, Shimabukuro M, Koyama K, Lee Y, Wang MY, Trieu F et al. Induction by leptin of uncoupling protein-2 and enzymes of fatty acid oxidation. Proceedings of the National Academy of Sciences of the USA $1997946386-6390$.

15 Shimabukuro M, Zhou YT, Lee Y \& Unger RH. Induction of uncoupling protein-2 mRNA by troglitazone in the pancreatic islets of Zucker diabetic fatty rats. Biochemical and Biophysical Research Communications 1997237 359-361.

16 Millet L, Vidal H, Andreelli F, Larrouy D, Riou J-P, Ricquier D et al. Increased uncoupling protein-2 and -3 mRNA expression during fasting in obese and lean humans. Journal of Clinical Investigation $19971002665-2670$.

17 Bouchard CH, Perusse L, Chagnon YC, Warden C \& Ricquier D. Linkage between markers in the vicinity of the uncoupling protein 2 gene and resting metabolic rate in humans. Human Molecular Genetics 19976 1887-1889.

18 Reaven GM, Lerner RL, Stern MP \& Farquhar JW. Role of insulin in endogenous hypertriglyceridemia. Journal of Clinical Investigation 196746 1756-1767.

19 Reaven GM, Javorski WC \& Reaven E. Diabetic hypertriglyceridemia. American Journal of Medical Sciences $1975269382-$ 389.

20 Reaven GM \& Greenfield MS. Diabetic hypertriglyceridemia: evidence for three clinical syndromes. Diabetes $19813066-75$.

21 Haffner SM, Fong D, Hazuda HP, Pugh JA \& Patterson JK. Hyperinsulinemia, upper body adiposity, and cardiovascular risk factors in non-diabetics. Metabolism 198837 338-345.

22 Laws A, Stefanick ML \& Reaven GM. Insulin resistance and hypertriglyceridemia in nondiabetic relatives of patients with noninsulin-dependent diabetes mellitus. Journal of Clinical Endocrinology and Metabolism 198969 343-347.

23 Taskinen MR. Hyperlipidaemia in diabetes. Baillieres Clinical Endocrinology and Metabolism 19904 743-775.

24 Taskinen MR. Insulin resistance and lipoprotein metabolism. Current Opinion in Lipidology 19956 153-160.

25 Ginsberg HN. Diabetic dyslipidemia: basic mechanisms underlying the common hypertriglyceridemia and low HDL cholesterol levels. Diabetes 199645 S27-S30.

26 Taskinen MR. Hyperinsulinism and dyslipidemias as coronary heart disease risk factors in NIDDM. Advances in Experimental Medicine and Biology 1993334 295-301.

27 Neel V. Diabetes mellitus: a 'thrifty' genotype rendered detrimental by progress? American Journal of Human Genetics 196214 353-362.

28 World Health Organization. Diabetes mellitus: Report of a WHO Study Group. World Health Organization Technical Report Series 1985727.

29 Breathnach R \& Chambon P. Organisation and expression of eukaryotic split genes coding for proteins. Annual Review of Biochemistry 198150 349-383.

30 Orita M, Suzuki Y, Sekiya T \& Hayashi K. Rapid and sensitive detection of point mutations and DNA polymorphisms using the polymerase chain reaction. Genomics 19895 874-879.

31 Solanes G, Vidal-Puig DG, Flier JS \& Lowell BB. The human uncoupling protein-3 gene. Genomic structure, chromosomal localization, and genetic basis for short and long form transcripts. Journal of Biological Chemistry 1997272 25433-25436.

32 Ravussin E, Lillioja S, Knowler WC, Christin L, Freymond D, Abbott WG et al. Reduced rate of energy expenditure as a risk factor for body weight gain. New England Journal of Medicine 1988 $318467-472$

33 Lowell BB, Susulic VS, Hamann A, Lawitts JA, Himms-Hagen J, Boyers BB et al. Development of obesity in transgenic mice after 
genetic ablation of brown adipose tissue. Nature 1993366740 742 .

34 Enerbäck S, Jacobsson A, Simpson EM, Guerra C, Yamashita H, Harper ME et al. Mice lacking mitochondrial uncoupling protein are cold-sensitive but not obese. Nature 1997387 90-94.

35 Urhammer SA, Fridberg M, Sørensen TIA, Echwald SM, Andersen T, Tybjærg-Hansen A et al. Studies of genetic variability of the uncoupling protein 1 gene in caucasian subjects with juvenileonset obesity. Journal of Clinical Endocrinology and Metabolism 199782 4069-4074.

36 Oppert JM, Vohl MC, Chagnon M, Dionne FT, Cassard-Doulcier AM, Ricquier D et al. DNA polymorphism in the uncoupling protein (UCP) gene and human body fat. International Journal of Obesity and Related Metabolic Disorders 199418 526-531.

37 Clement K, Ruiz J, Cassard-Doulcier AM, Bouillaud F, Ricquier D, Basdevant A et al. Additive effect of $A \rightarrow G(-3286)$ variant of the uncoupling protein gene and the Trp64Arg mutation of the beta 3-adrenergic receptor gene on weight gain in morbid obesity. International Journal of Obesity and Related Metabolic Disorders $1996201062-1066$.

38 Urhammer SA, Dalgaard LT, Sørensen TIA, Møller AM, Andersen T, Tybjærg-Hansen A et al. Mutational analysis of the coding region of the uncoupling protein 2 gene in obese NIDDM patients: impact of a common amino acid polymorphism on juvenile and maturity onset forms of obesity and insulin resistance. Diabetologia $1997401227-1230$.

39 Elbein SC, Leppert M \& Hasstedt S. Uncoupling protein 2 region on chromosome 11q13 is not linked to markers of obesity in familial Type 2 diabetes. Diabetes 199746 2105-2107.

Received 11 February 1998

Accepted 27 April 1998 